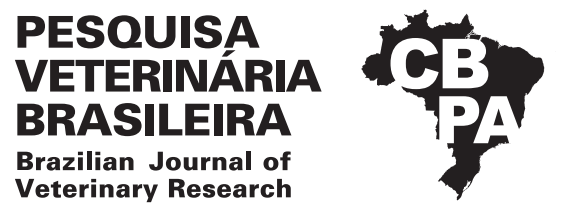

Pesq. Vet. Bras. 38(11):2159-2165, novembro 2018 DOI: $10.1590 / 1678-5150-P V B-5325$

Original Article

Morfofisiologia/Morphophysiology

ISSN 0100-736X (Print)

ISSN 1678-5150 (Online)

\title{
Morphological analysis of the elastic and collagen fibers in the ram penis ${ }^{1}$
}

\author{
Bruno Cesar Schimming ${ }^{2 *}$ and Gustavo N. Moraes ${ }^{3}$
}

\begin{abstract}
Schimming B.C. \& Moraes G.N. 2018. Morphological analysis of the elastic and collagen fibers in the ram penis. Pesquisa Veterinária Brasileira 38(11):2159-2165. Departamento de Anatomia, Universidade Estadual Paulista, Cx. Postal 510, Botucatu, SP 18618-970, Brazil. E-mail: bruno.schimming@unesp.br

The penis represents the organ of the male's copulation. It is essential to know the reproductive biology and the morphology of the reproductive organs to increase animal production. In order to contribute to this knowledge and provides information on the ram reproductive morphology, the purpose of this work was to describe the distribution, based on light microscopy, of the collagen and elastic fibers in the ram penis. For that, were collected transverse fragments of the penis (root, sigmoid flexure, body and glans) of seven rams. The specimens were fixed in paraformaldehyde for $24 \mathrm{~h}$ and destined for the histological routine. The extracellular matrix of the ram penis was composed of collagen and elastic fibers. The penis was enveloped by the tunica albuginea, consisting essentially of collagen fibers, which were arranged in two layers: an outer longitudinal and an inner circular. This tunic emitted septa that penetrated the corpus cavernosum. The elastic fibers appeared transversely and longitudinally in the corpus cavernosum, corpus spongiosum, and next to the neurovascular bundle of the penis. This structure was not different to that reported for other domestic ruminants such as cattle and buffaloes.
\end{abstract}

INDEX TERMS: Morphological analysis, collagen fibers, extracellular matrix, ram, penis, elastic fibers.

\begin{abstract}
RESUMO.- [Análise morfológica de fibras elásticas e colágenas no pênis de ovinos.] $O$ pênis representa $o$ órgão da cópula do macho. É fundamental que se conheça a biologia reprodutiva e a morfologia dos órgãos reprodutores para o incremento da produção animal. Com o objetivo de contribuir para este conhecimento e fornecer informações sobre a morfologia reprodutiva de ovinos, o propósito deste trabalho foi descrever a distribuição, com base na microscopia de luz, das fibras colágenas e elásticas no pênis de ovinos. Para tanto, foram coletados fragmentos transversais do pênis (raiz, flexura sigmoide, corpo e glande) de sete ovinos. Os exemplares foram fixados em paraformaldeído por $24 \mathrm{~h}$ e destinados à rotina histológica. A matriz extracelular do pênis de ovinos estava constituída por fibras colágenas e
\end{abstract}

\footnotetext{
${ }^{1}$ Received on October 16, 2017.

Accepted for publication on March 19, 2018.

${ }^{2}$ Departamento de Anatomia, Instituto de Biociências de Botucatu, Universidade Estadual Paulista (Unesp), Distrito de Rubião Junior, Cx. Postal 510, Botucatu, SP 18618-970, Brazil. *Corresponding author: bruno.schimming@unesp.br

${ }^{3}$ Veterinary Medicine student, Faculdade de Medicina Veterinária e Zootecnia, Universidade Estadual Paulista (Unesp), Campus de Botucatu, Distrito de Rubião Júnior, Botucatu, SP 18618-970.
}

elásticas. 0 pênis estava envolvido pela túnica albugínea, formada essencialmente por fibras colágenas, que estavam arranjadas em duas camadas: longitudinal externa e circular interna. Esta túnica emitiu septos que penetraram no corpo cavernoso. As fibras elásticas apareceram de modo transversal e longitudinal nos corpos cavernoso e esponjoso e junto ao feixe vásculo-nervoso do pênis de ovinos. Esta estrutura mostrou-se similar ao encontrado em outros ruminantes domésticos como bovinos e bubalinos.

TERMOS DE INDEXAÇÃO: Análise morfológica, fibras colágenas, matriz extracelular, ovinos, pênis, fibras elásticas.

\section{INTRODUCTION}

According to the architecture of the corpus cavernosum, the penis of domestic animals is classified into two types: fibroelastic and musculocavernous penises. The fibroelastic type has small and confined blood spaces, and these spaces are divided by a large amount of fibroelastic tissue. This type of penis, when quiescent, exhibits a sigmoid flexure. The fibroelastic penis appears in ruminants and boars (Hafez \& Hafez 2004, Dyce et al. 2010). Stallions, dogs and rabbits 
have the musculocavernous type of penis. In this type of penis, blood spaces are relatively larger, and the lining and septa are more delicate and more muscular (Hafez \& Hafez 2004, Dyce et al. 2010, Ribeiro et al. 2013).

The rabbit penis is covered by a capsule of connective tissue, the tunica albuginea, which projects intracavernous septa, especially in the corpus cavernosum. There are elastic fibers in the corpus cavernosum, corpus spongiosum, and in the tunica albuginea of the penis (Maia et al. 2006). The concentration of elastic fibers in different penile regions is related to age-related changes in rabbits. From one month of life, rabbits have a gradual increase in the concentration of these fibers. This trend is interrupted at two years, which may be related to initial changes due to senescence of the animals (Abidu-Figueiredo et al. 2013).

There are few reports on the distribution of elastic, collagen and muscle fibers in the penis in domestic or wild animals. Babinski et al. (2005) studied the boar penis in order to verify the distribution of smooth muscle fibers and the volumetric density of the elastic fiber system. Elastic fibers appeared in both the corpus spongiosum and corpus cavernosum of all the animals studied. The authors suggest that the large amount of elastic fibers and the distribution of smooth muscle cells between the endothelium could represent the role that these structures would exert in the process of penile erection in boars. The zebu and bubaline penis, which is a fibroelastic type, has much of its rigidity conferred by the collagen and elastic fibers present in the extracellular matrix. Many collagen fibers were found in the corpus cavernosum and spongiosum of these penises, which is a common pattern in animals with this type of penis (Ribeiro et al. 2013). The extracellular matrix of penis in intact and neutered cats was analyzed and the findings of this study showed a significant decrease in the density of the elastic fibers and a significant increase of the density of the collagen fibers in the corpus spongiosoum in neutered cats, suggesting that hormonal deprivation caused modifications in the extracellular matrix in the penises of neutered cats (Borges et al. 2017).

The extracellular matrix formed by the collagen and elastic fibers is a dynamic cellular skeleton that plays an important role in modulating the physiological function of the cavernous tissue. This regulates cell morphology, movement, growth and differentiation. In the cavernous body, the matrix consists of a fibrillar collagen network that is closely connected to smooth muscle trabeculae (Traish \& Kim 2005). Type I and II collagen are the major components of the cavernous body of the penis (Luangkhot et al. 1992, Moreland et al. 1995, Raviv et al. 1997).

The system of elastic and collagen fibers is therefore an important structure for penile erection and allows adequate resistance during the return of the penis to a detumescence (Hsu et al. 1994, Sattar et al. 1994, Da Silva \& Sampaio 2002, Bastos et al. 2004, Babinski et al. 2005). Therefore, it may be considered that the extracellular matrix of the corpus cavernosum is essential for normal penile erection and is involved in erectile dysfunction. The structural description and quantification of the elements of the extracellular matrix represent a good method to evaluate the morphological and functional alterations associated with pathological conditions in humans and animal models (Siracusano et al. 1996, Maia et al. 2006)
The gross anatomy of the ram penis has been studied and described in veterinary anatomy treatises such as Dyce et al. (2010), but there is no information about the elements of the penile connective tissue in these animals. Thus, the purpose of this study was to provide morphological data on the distribution of collagen and elastic fibers in the ram penis, because is essential to know the reproductive biology and the morphology of the reproductive organs to increase animal production.

\section{MATERIALS AND METHODS}

Penises of seven rams, sexually mature, were used in this study. The animals were Santa Ines, Dorper and Texel breeds. The samples were collected after the slaughter and inspection procedures of the animals, in a slaughterhouse. After collection, the penises were sectioned in regions such as root, sigmoid flexure, penile body and glans.

The tissues were fixed in 4\% paraformaldehyde for $24 \mathrm{~h}$. After histological fixation, tissue samples were washed for 24 hours in running water and submitted for inclusion in Paraplast ${ }^{\mathrm{TM}}$ (Sigma, St Louis/MO, USA). Following inclusion, $5 \mu \mathrm{m}$ thick sections were cut and stained in Hematoxylin and Eosin (HE), Masson's Trichrome, Calleja and Picrosirius red. The slides were observed, analyzed and photographed in the Olympus BX41 optic microscope connected to a digital camera Olympus SC30, Department of Anatomy, Institute of Biosciences of Botucatu, Unesp. The blades stained in Picrosirius red were analyzed in the polarized light microscope Leica DMLB (Leica Microsystems, Mannheim, Germany) The images were captured by a digital camera Leica DFC 300FX and processed with Leica Qwin V3 software, Department of Morphology, Institute of Biosciences of Botucatu, Unesp.

\section{RESULTS}

The ram has a fibroelastic penis, with a characteristic sigmoid flexure. There were no morphological differences, by light microscopy, between of the penile regions such as root, sigmoid flexure, and penile body. The penis was covered by a dense connective tissue capsule named tunica albuginea. The tunica albuginea involved the penile structure, which was formed by the corpus cavernosum and corpus spongiosum. The corpus cavernosum was located dorsolateral, deep into the tunica albuginea, while the corpus spongiosum enveloped the urethra (Fig.1 and 2).

The histological analysis confirmed that the extracellular matrix of the ram penis was basically formed by elastic and collagen fibers. The tunica albuginea was composed essentially of collagen fibers (Fig.1-4), which were arranged in two layers: an outer longitudinal and an inner circular (Fig.1A,B, 2C,D). The inner circular layer of the tunica albuginea projects intracavernosal septa in the corpus cavernosum. These septa consisted mainly of collagen fibers. The collagen fibers were the most abundant component of the tunica albuginea, septa, and corpus cavernosum (Fig.2 and 4).

An irregular system of elastic fibers was observed in the studied penises. Elastic fibers were intercalated between the collagen fiber bundles of the tunica albuginea and its septa. These fibers were abundant in the neurovascular bundles, around the blood vessels and nerves. There was a predominance of elastic fibers in the cavernous structure of the corpus spongiosum of the ram penis and in the neurovascular bundles 

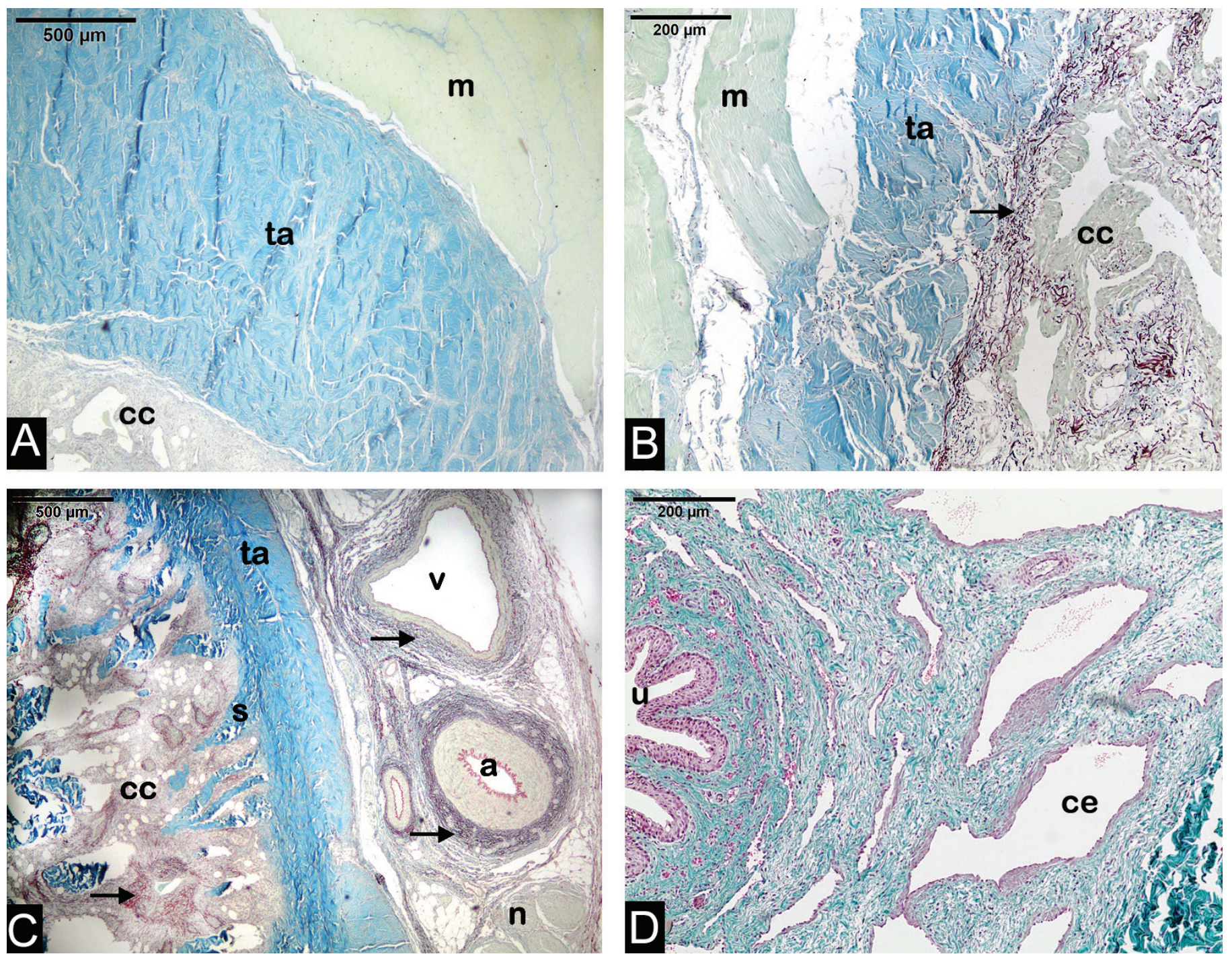

Fig.1. (A,B) Regions of the root and (C,D) the sigmoid flexure in the ram penis. Ischiocavernous muscle (m), tunica albuginea (ta), septa of tunica albuginea (s), corpus cavernosum (cc), corpus spongiosum (ce), elastic fibers (arrows), urethra (u), artery (a), vein (v) and nerve (n) that comprised the neurovascular bundle of the penis. Note the collagen fibers in blue in Calleja stain indicating that tunica albuginea consists mainly of collagen fibers. (A,C) Calleja, bar $=500 \mu \mathrm{m}$. (B) Calleja, bar $=200 \mu \mathrm{m}$. (D) Masson's trichrome, bar $=200 \mu \mathrm{m}$.

(Fig.1-3). This system of elastic fibers was composed of elastic fibers that were appeared in several ways, longitudinally and transversely bundles (Fig.3). The region of the ram penile glans was formed only by a corpus spongiosum, which was formed by the system of elastic fibers (Fig.2E,F).

\section{DISCUSSION}

The ram penis contains two erectile structures, the supero-lateral corpus cavernosum and the ventral corpus spongiosum that surrounds the urethra. The wild boar penis has a similar structure with a tunica albuginea covering the corpus cavernosum and spongiosum (Babinski et al. 2005). In this study, the extracellular matrix of the ram penis was described and is formed by collagen and elastic fibers. Ribeiro et al. (2013) claimed that the fibroelastic penis of cattle and water buffalo is an organ of great interest in animal breeding, due to the presence of extracellular matrix which is involved in penile erection. Trabeculae of the corpus cavernosum represent the major morphological structure involved in penile erection. They are composed of endothelial cells, smooth muscle cells and extracellular matrix (Sattar et al. 1994, Sampaio et al. 1998, Ribeiro et al. 2013). The integrity of the corpus spongiosum is also important for the erection mechanism since it acts synergistically with the tunica albuginea and the corpus cavernosum (Conti et al. 1988, Ribeiro et al. 2013).

Penile erection occurs by the transformation of erectile tissue and vasculature from a state of minimally perfused sagging to one of engorgement with blood. This process is mediated by vascular, neuronal, hormonal, and psychological components. There is relaxation of the smooth muscles present in the blood vessels and trabeculae of the corpus cavernosum, which leads to an increase in blood flow to the penis, which compresses the venules that lie just below the 

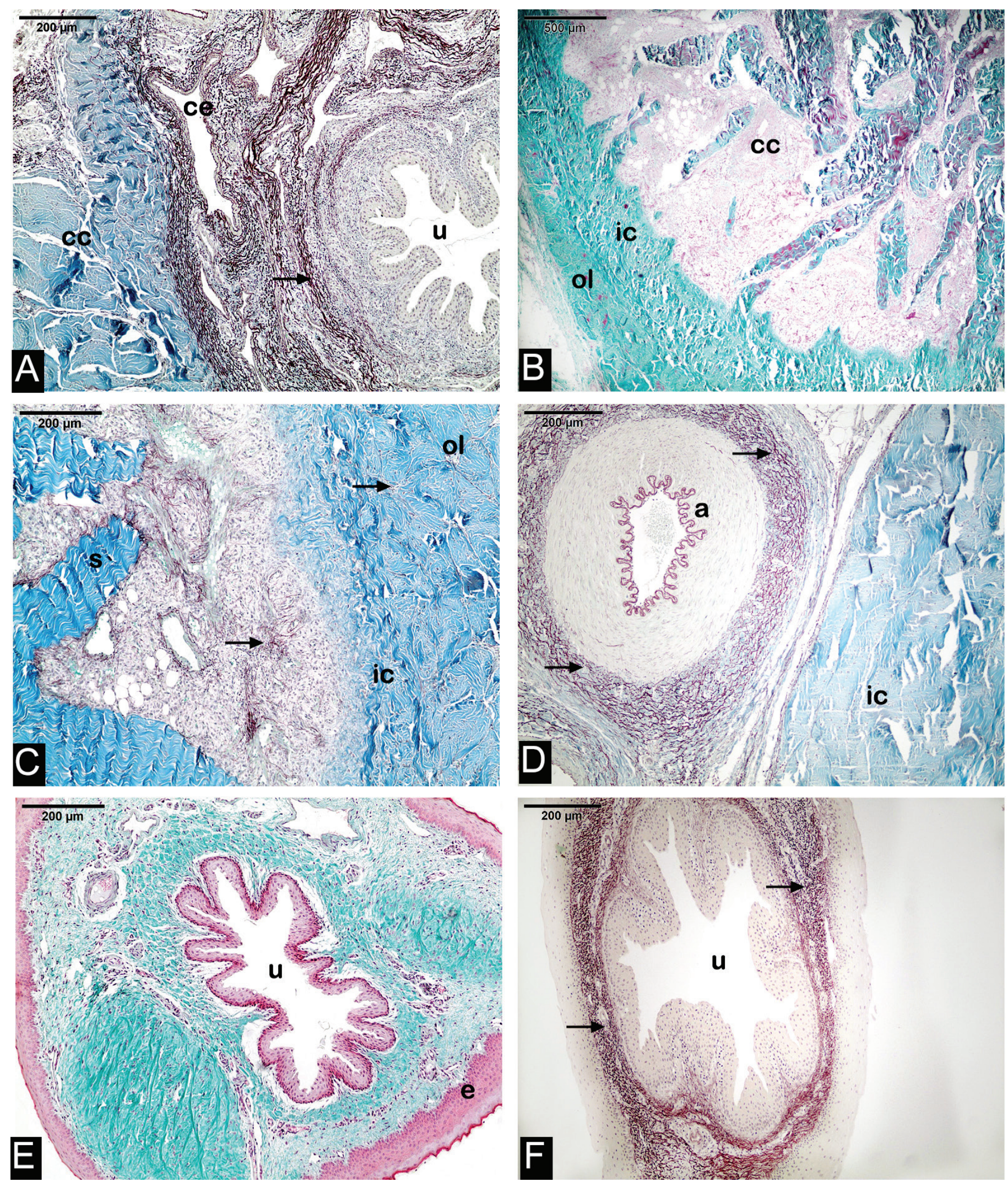

Fig.2. (A-D) Ram penile body and (E,F) glans. Corpus cavernosum (cc), corpus spongiosum (ce), elastic fibers (arrows), urethra (u), artery (a), and lining epithelium of the glans (e). The tunica albuginea are arranged in two layers: an outer longitudinal (ol) and an inner circular (ic). These two layers are comprised basically of collagen fibers (in blue in Calleja stain). (A,C,D,F) Calleja, bar $=200 \mu \mathrm{m}$. (B) Masson's Trichrome, bar $=500 \mu \mathrm{m}$. (E) Masson's Trichrome, bar $=200 \mu \mathrm{m}$.. 

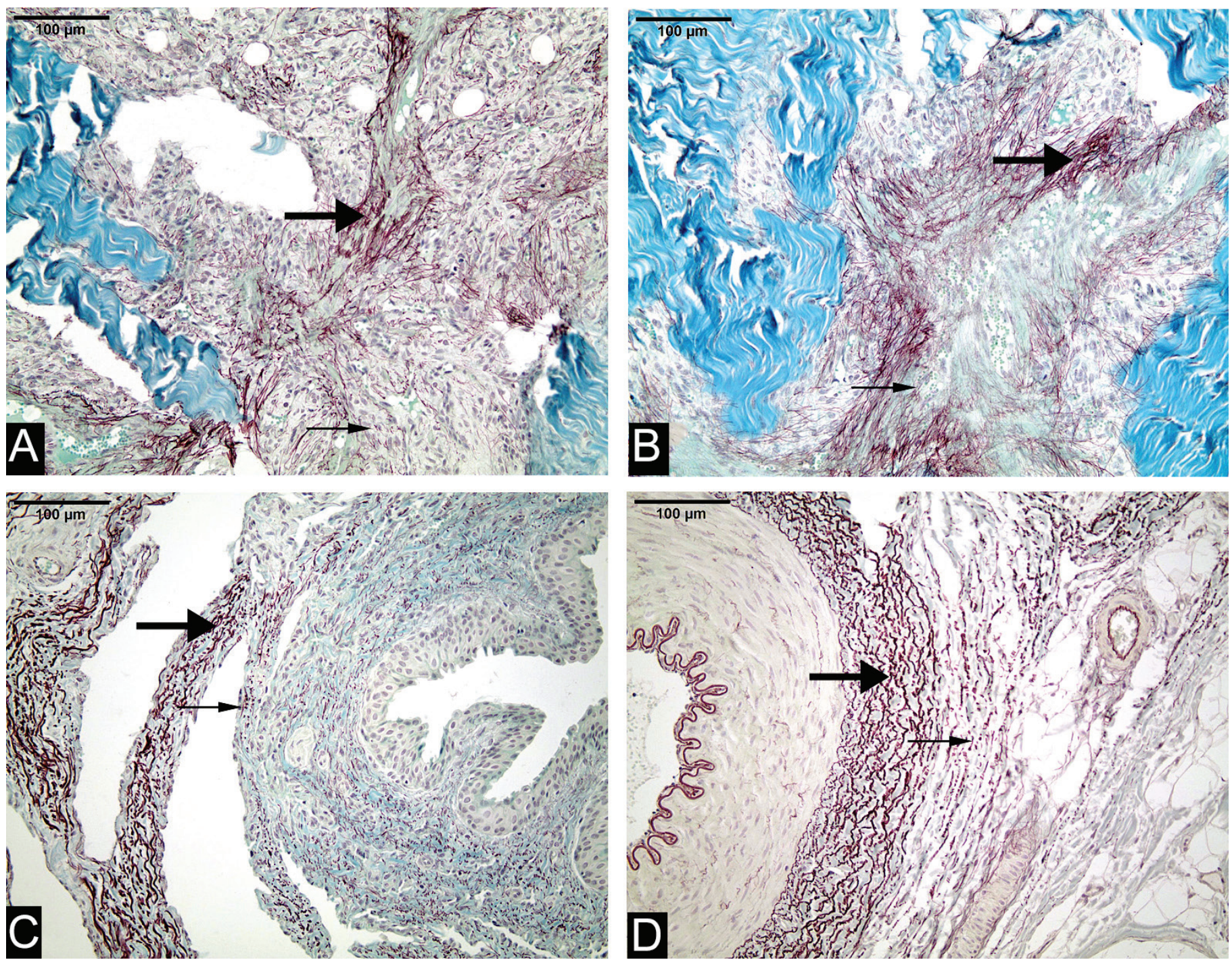

Fig.3. (A-D) Elastic fibers in the region of the body of the ram penis. Elastic fibers arranged transversely (thick arrows) and longitudinally

(thin arrows). Note the collagen fibers in blue. Thus, the extracellular matrix of the ram penis is formed by elastic and collagen fibers.

Calleja, bar $=100 \mu \mathrm{m}$.

tunica albuginea against it, leading to drainage occlusion (Mostafa et al. 2013).

The ram tunica albuginea was divided into two layers: an outer longitudinal and an inner circular, which is in agreement with that reported for bovine and buffalo penises (Ribeiro et al. 2013). The collagen fibers appear mainly in the two layers of the tunica albuginea and in their septa, which is also similar to that described for the tunica albuginea of the corpus cavernosum of cattle and buffalo (Ribeiro et al. 2013). The organization of collagen fibers in the tunica albuginea of ram are in agreement with reports on the cattle and water buffalo penis (Ribeiro et al. 2013). The tunica albuginea, a connective tissue sheath which surrounds the cavernous body, also plays an important role in erection, and is essential for penile compliance, venous occlusion, flexibility, extensibility, and rigidity (Brock et al. 1997).

Pinheiro et al. (2000) have been studied the structure of the corpus cavernosum of the rat penis, and reported that the collagen fibers represented the main component of the trabeculae of the corpus cavernosum of the mouse penis. These authors claimed that the extracellular matrix of the corpus cavernosum is essential for the normal erection of the penis and seems to be related to several erectile dysfunctions.

The ram penis is a fibroelastic penis. The elastic fiber system appeared in the corpus spongiosum and corpus cavernosum. The boar penis had a well developed elastic fiber system in the corpus spongiosum and cavernosum, but there was a higher volume density of these fibers in the corpus spongiosum when compared to the corpus cavernosum (Babinski et al. 2005). In this study, the elastic fibers, besides constituting the extracellular matrix of the cavernous tissue, are also abundant near the blood vessels and nerves. Several studies reported that tissues, normally submitted to stretching, present a large amount of elastic fibers (Cotta-Pereira et al. 1976, Kreis \& Vale 1993, Ribeiro et al. 2013), and this could explain the presence of abundant elastic fibers in the cavernosus structure of the ram penis. 

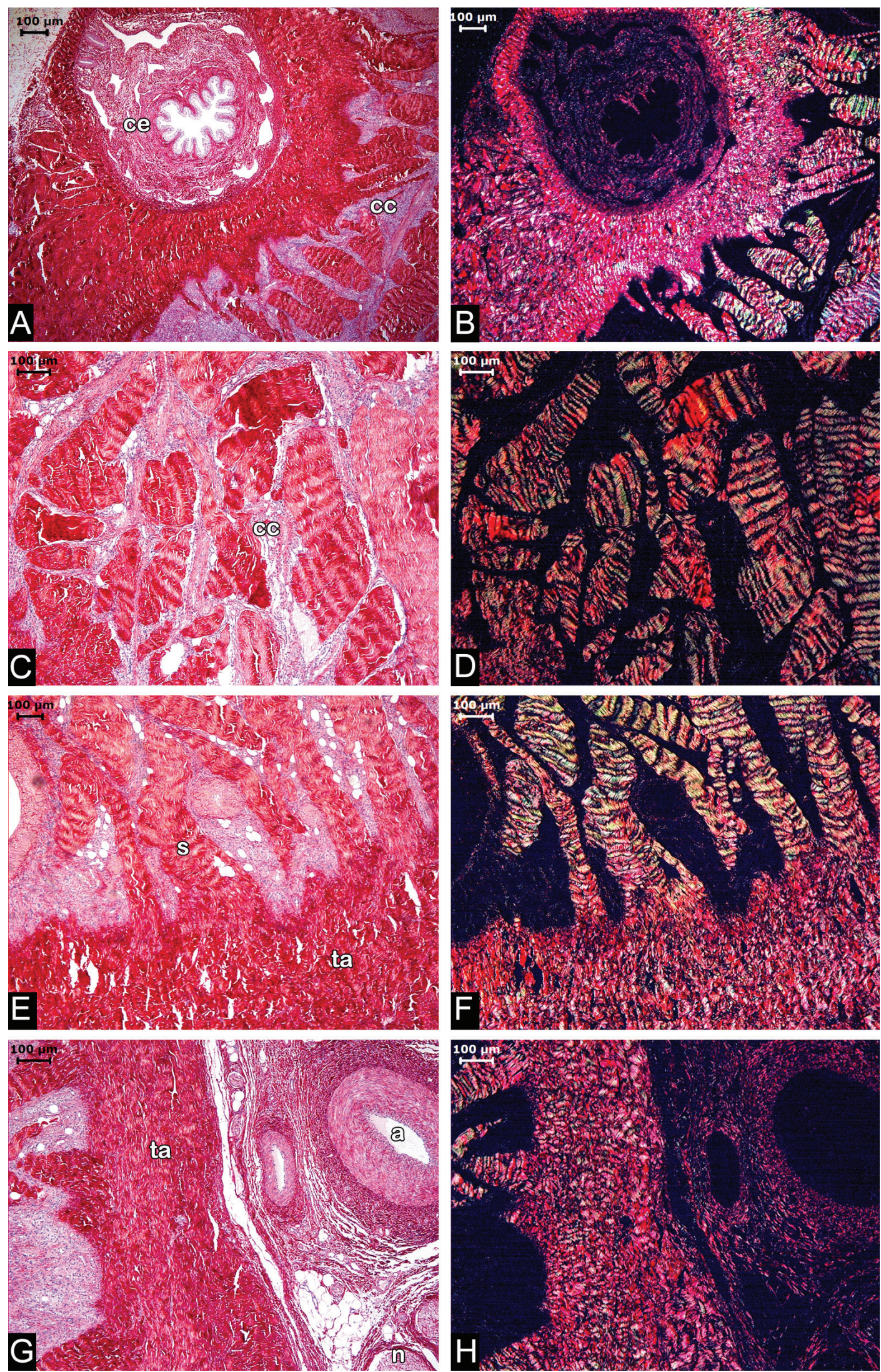

Fig.4. (A-H) Corpus spongiosum (ce), corpus cavernosum (cc) and tunica albuginea (ta) of ram penis. Note the great amount of collagen fibers in the corpus cavernosum (cc), and in the septa (s) of the tunica albuginea (ta). Neurovascular bundles with artery (a) and nerve (n). (A,C,E,G) Picrosirius Red under conventional light and (B,D,F,H) under polarized light, bar $=100 \mu \mathrm{m}$. 


\section{CONCLUSION}

The arrangement of the elastic and collagen fibers in the ram penis suggests that this animal shows a typical extracellular matrix corresponding to the fibroelastic penis, similar to other mammals such as the boar, bull and buffalo.

Like these fibers play an important role in penile erection and detumescence, this morphological knowledge can contribute to the reproduction routine in veterinary medicine.

Acknowledgements.-The authors would like to thank Prof. Dr. Luis Antonio Justulin Júnior, Department of Morphology, Institute of Biosciences of Botucatu, Unesp, for providing the polarized light microscope.

\section{REFERENCES}

Abidu-Figueiredo M., Costa W.S., Chagas M.A., Sampaio F.J.B. \& Cardoso L.E.M. 2013. Age-related changes in the concentration of elastic fibers in different regions of the rabbit penis. Acta Cir. Bras. 28(5):378-384. <http://dx.doi. org/10.1590/S0102-86502013000500010> <PMid:23702941>

Babinski M.A., Brito-Gitirana L., Chagas M.A., Abidu-Figueiredo M., Costa W.S. \& Sampaio F.J.B. 2005. Immunohistochemical analysis of smooth muscle cells and volumetric density of the elastic system fibers of wild boar (Sus scrofa) penis. Anim. Reprod. Sci. 86(3/4):317-328. <http://dx.doi. org/10.1016/j.anireprosci.2004.08.002> <PMid:15766809>

Bastos A.L., Silva E.A., Costa W.S. \& Sampaio F.J.B. 2004. Concentration of elastic fibers in the male urethra during human fetal development. BJU Int. 94(4):620-623. <http://dx.doi.org/10.1111/j.1464-410X.2004.05012. x><PMid:15329125>

Borges N.C.S., Pereira-Sampaio M.A., Pereira V.A., Abidu-Figueiredo M. \& Chagas M.A. 2017. Effects of castration on penile extracellular matrix morphology in domestic cats. J. Feline Med. Surg. 19(12):1261-1266. <http://dx.doi.org/10.1177/1098612X16689405> <PMid:28176530>

Brock G., Hsu G.L., Nunes L., Von Heyden B. \& Lue T.F. 1997. The anatomy of the tunica albuginea in the normal penis and Peyronie's disease. J. Urol. 157(1):276-281.<http://dx.doi.org/10.1016/S0022-5347(01)65359-X> <PMid:8976279>

Conti G., Virag R. \& von Niederhäusern W. 1988. The morphological basis for the polster theory of penile vascular regulation. Acta Anat. 133(3):209-212. <http://dx.doi.org/10.1159/000146641> <PMid:3227779>

Cotta-Pereira G., Rodrigo G. \& Bittencourt-Sampaio S. 1976. Oxylatan, elaunin and elastic fibers in the human skin. J. Investigative Dermatol. 66(3):143-148. <http://dx.doi.org/10.1111/1523-1747.ep12481882><PMid:1249442>

Dyce K.M., Sack W.O. \& Wensing C.J.G. 2010. Tratado de Anatomia Veterinária. 4⿳a ed. Elsevier, Rio de Janeiro, p.193-195.

Hafez E.S.E. \& Hafez B. 2004. Reprodução Animal. 7ạ ed. Manole, São Paulo, p.3-10.

Hsu G.-L., Brock G., Heyden B.V.O.N., Nunes L., Lue T.F. \& Tanagho E.A. 1994. The distribution of elastic fibrous elements within the human penis. BJU Int. 73(5):566-571. <http://dx.doi.org/10.1111/j.1464-410X.1994. tb07645.x><PMid:8012781>
Kreis T. \& Vale R. 1993. Guidebook to the Extracellular Matrix and Adhesion Proteins. Oxford University Press, Oxford, p.40-51.

Luangkhot R., Rutchik S., Agarwal V., Puglia K., Bhargava G. \& Melman A. 1992. Collagen alterations in the corpus cavernosum of men with sexual dysfunction. J. Urol. 148(2 Pt 1):467-471. <http://dx.doi.org/10.1016/ S0022-5347(17)36630-2><PMid:1635159>

Maia R.S., Babinski M.A., Figueiredo M.A., Chagas M.A., Costa W.S. \& Sampaio F.J. 2006. Concentration of elastic system fibers in the corpus cavernosum, corpus spongiosum, and tunica albugínea in the rabbit penis. Int. J. Impot. Res. 18(2):121-125.<http://dx.doi.org/10.1038/sj.ijir.3901404> <PMid:16224492>

Moreland R.B., Traish A., McMillin M.A., Smith B., Goldstein I. \& Saenz de Tejada I. 1995. PGE1 supresses the induction of collagen synthesis by transforming growth factor-beta 1 in human corpus cavernosum smooth muscle. J. Urol. 153(3 Pt 1):826-834. <PMid:7861547>

Mostafa M.E., Senbel A.M. \& Mostafa T. 2013. Effect of chronic low-dose Tadalafil on penile cavernosous tissues in diabetic rats. Urology 81(6):1253-1259. <http://dx.doi.org/10.1016/j.urology.2012.12.068><PMid:23726447>

Pinheiro A.C.A.D., Costa W.S., Cardoso L.E.M. \& Sampaio F.J.B. 2000. Organization and relative contento f smooth muscle cells and extracellular matrix components in the corpus cavernosum of the rat penis. J. Urol. 164:1802-1806. <http://dx.doi.org/10.1016/S0022-5347(05)67110-8> $<$ PMid:11025773>

Raviv G., Kiss R., Vanegas J.P., Petein M., Danguy A., Schulman C. \& Wespes E. 1997. Objective measurement of the different collagen types in the corpus cavernosum of potent and impotent men: an immunohistochemical staining with computerized-image analysis. World J. Urol. 15(1):50-55. <http:// dx.doi.org/10.1007/BF01275157><PMid:9066095>

Ribeiro I.C.A., Abidu-Figueiredo M., Costa F.B., Pereira-Sampaio M.A. \& Chagas M.A. 2013. Stereological study of the elastic fiber and smooth muscle cell system in the bovine and buffalo penis. Pesq. Vet. Bras. 33(Suppl. 1):107112. <http://dx.doi.org/10.1590/S0100-736X2013001300017>

Sampaio F.B., Pinto J.F., Silva-Costa W. \& Pereira M.S. 1998. Quantitative analysis of smooth muscle fibers in corpus cavernosum of human fetuses. J. Urol. 159(6):2226-2228. <http://dx.doi.org/10.1016/S0022-5347(01)63310-X> $<$ PMid:9598574>

Sattar A.A., Wespes E. \& Schulman C.C. 1994. Computerized measurement of penile elastic fibers in potent and impotent men. Eur. Urol. 25(2):142-144. <http://dx.doi.org/10.1159/000475269> <PMid:8137855>

Silva E.A. \& Sampaio F.J.B. 2002. Uretral extensibility applied to reconstructive surgery. J. Urol. 167(5):2042-2045. <http://dx.doi.org/10.1016/S00225347(05)65079-3><PMid:11956434>

Siracusano S., Bosincu L., Marras V., Pisano I., Deriu M., Marceddu S., Trignano M. \& Belgrano E. 1996. Preliminary reports on morphological and ultrastructural changes in the corpora cavernosa of the rat after chronic arterial obstruction. Arch. Esp. Urol. 49(2):191-195. <PMid:8702334>

Traish A.M. \& Kim N.N. 2005. The physiological role of androgens in penile erection: Regulation of corpus cavernosum structure and function. J. Sexual Med. 2(6):759-770.<http://dx.doi.org/10.1111/j.1743-6109.2005.00094. $\mathrm{x}><$ PMid:16422801> 